\title{
ECOLOGICAL ANALYSIS OF BUTTERFLIES AND DAY-FLYING MOTHS DIVERSITY OF THE GOURAYA NATIONAL PARK (ALGERIA)
}

\author{
S. Berkane ${ }^{1 \star}$, H. Hafir ${ }^{2}$, R. Moulaï ${ }^{1}$
}

${ }^{1}$ Laboratoire de zoologie appliquée et d'écophysiologie animale, Faculté des sciences de la nature et de la vie, Université de Bejaia-06000 Bejaia, Algérie

${ }^{2}$ Direction général des Forêts, Alger, Algérie

E-mails: soniaberkane2000@hotmail.com,moulai741@hotmail.com

${ }^{*}$ Corresponding author

S. Berkane (https://orcid.org/0000-0003-0771-4797)

Ecological Analysis of Butterflies and Day-Flying Moths Diversity of the Gouraya National Park (Algeria). Berkane, S., Hafir, H., Moulaï, R. - This work represents an initial analysis of butterflies and day-flying moths of the Gouraya National Park (Algeria). Forty-eight field-surveys were made between February 2011 and January 2012, in three stations (the cliff, the low matorral and the high matorral). It allowed us to identify 38 species, belonging to 6 families: Lycaenidae (13 species), Nymphalidae (10 species), Pieridae ( 9 species), Papilionidae (2 species), Hesperiidae (2 species), Zygaenidae (1 species) and Sphingidae (1 species). The low matorral and cliff were the richest stations, with 33 species for the first one and 23 species for the latter. Only seven species were observed in the high matorral where the highest centesimal frequency was recorded for the Pararge aegeria $(47.83 \%)$. This species records the highest frequency of occurrences in all 3 stations. The low matorral $\left(\mathrm{H}^{\prime}=4.25 \mathrm{bits}, \mathrm{E}=0.84\right)$ proved to be the most diversified and balanced station.

Key words: Gouraya National Park, butterfly, day-flying moth, ecology, diversity.

\section{Introduction}

Inventories are more necessary than ever today in the face of the disappearance of entomofauna diversity (Ouin et al., 2000; Lafranchis, 1997). Butterflies are excellent bio-indicators of environmental quality. Indeed, their great diversity and varied ecological requirements make them a taxonomic group of choice for biodiversity monitoring in a wide range of terrestrial environments (Tarrier \& Delacre, 2008; Manil et al., 2007; Pasquet, 2006).

A recent systematic and ecological catalogue of butterflies were established for Algeria (Tennent, 1996). It was followed by an inventory of butterflies inhabiting the most interesting habitats in north-eastern Algeria, in particular wetlands (Samraoui, 1998). More recently work on the diversity and abundance of butterfly species were directed at agricultural plots in central northern Algeria (Remini \& Moulaï, 2015) or on the Belezma National Park in the Aurés region (Berkane et al., 2019).

Within the coastal ecosystems of Kabylies-Numidia (Véla \& Benhouhou, 2007), a particular sector: Gouraya National Park (GNP) is famous for its endemic plant species and associations, and has long attracted the attention of scientists (Pons \& Quezel, 1955). Despite its protected status, the region's social and tourist needs make it a highly coveted area. The most serious threats to this protected area, and therefore to the butterfly populations it shelters, consist of overcrowding (the influx of tourists and the lack of civic-mindedness) and the anthropogenic destruction of habitats (urbanization, clearing, quarries, etc.) (Rebbas, 2014). 
Noting that to date no study has made it possible to identify the butterflies present in this protected area. The present work therefore focuses on an inventory of local populations of the butterflies and day-flying moths in order to assess their wealth, composition and ecology.

\section{Material and methods}

Study area and sites. The GNP is located on the eastern coast of Algeria. It is part of the coastal ranges of the Tellian Atlas. With an area of 2080 ha, it occupies $10.2 \%$ of the territory of the Wilaya of Bejaia. It is bounded on the North by the Mediterranean Sea, on the East side by the pointe noire to the Cap-Bouac, on the South by the city of Bejaïa and the road 24, and on the West by the village Issoumer up to Boulimat beach. In 2004, this park was classified as biosphere reserve by the international coordinating council of the Man and Biosphere (MAB) program of UNESCO in Paris (Rebbas, 2002; Vela \& Benhouhou, 2007; Boumecheikh, 2011; Moulaï \& Mostefai, 2015) (fig. 1). According to the Emberger system (1955) adapted by Daget (1977) with temperatures in degrees Celsius, The GNP is situated in a subhumid bioclimatic environment during warm winter $(\mathrm{Q} 2=124)$. The weather station of Bejaia records on average $762 \mathrm{~mm}$ of rain per year. The average minimum temperature for the coldest month is $7.5^{\circ} \mathrm{C}$ and the maximum temperature for the hottest month is $29.7^{\circ} \mathrm{C}$ (Rebbas et al., 2011).

Three stations were chosen within the GNP: a cliff, a low matorral and a high matorral.

The cliff ( $36^{\circ} 46^{\prime} 12.21^{\prime \prime} \mathrm{N} 5^{\circ} 06^{\prime} 04.17^{\prime \prime}$ E, altitude: $399 \mathrm{~m}$ ) (fig. 1 - Station A) is located in the North-East of the park, at Cape Carbon. It is bordered on the north by the Cape Carbon lighthouse zone, on the East and West by the Mediterranean Sea and it is crossed by a tourist track. This habitat is determined by the presence of compact calcareous rocks exposed to the North, forming abrupt and high vertical or slightly sloping coasts (85-95\% inclination). The vegetation covers $45 \%$ of the station and the rock outcrops can be up to $55 \%$. Its vegetation does not exceed 1 to 1.5 meters. It consists mainly of: Quercus coccifera (L., 1753), Phillyrea latifolia ((L.) Maire (1934)), Bupleurum plantagineum (Desf., 1798) and Chamaerops humilis (L., 1753). Let us note the presence of a Euphorbia dendroides (L., 1753) formation, unique to the Mediterranean.

The low matorral $\left(36^{\circ} 46^{\prime} 03.90^{\prime \prime} \mathrm{N} 5^{\circ} 04^{\prime} 08.14^{\prime \prime} \mathrm{E}\right.$, altitude: $\left.333 \mathrm{~m}\right)$ (fig. 1 - Station B) is located in south-eastern art of the Park. It bordered on the North by Jebel Gouraya and on the South by the city of Bejaia. A tourist track crosses it on both sides. It is usually on fairly low slopes $(24 \%)$. Its general recovery does not exceed $60 \%$ and it is characterized by the dominance of a shrub layer which can reach 1 to 2 meters high. The plant species that characterize it are: Quercus coccifera, Pistacia lentiscus (L., 1753), Myrtus communis (L., 1753), Ceratonia siliqua (L., 1753) and Pinus halepensis (Mill., 1768).

The high matorral $\left(36^{\circ} 45^{\prime} 59.39^{\prime \prime} \mathrm{N} 5^{\circ} 05^{\prime} 53.58^{\prime \prime}\right.$ E, elevation: $399 \mathrm{~m}$ ) (fig. 1 - Station C) is located in the integral of the Park. It's bounded by the tourist route that runs through the park. This habitat is generally found on medium-slope lands (35\%). The vegetation cover is greater than $89.44 \%$. It's determined by a relatively high

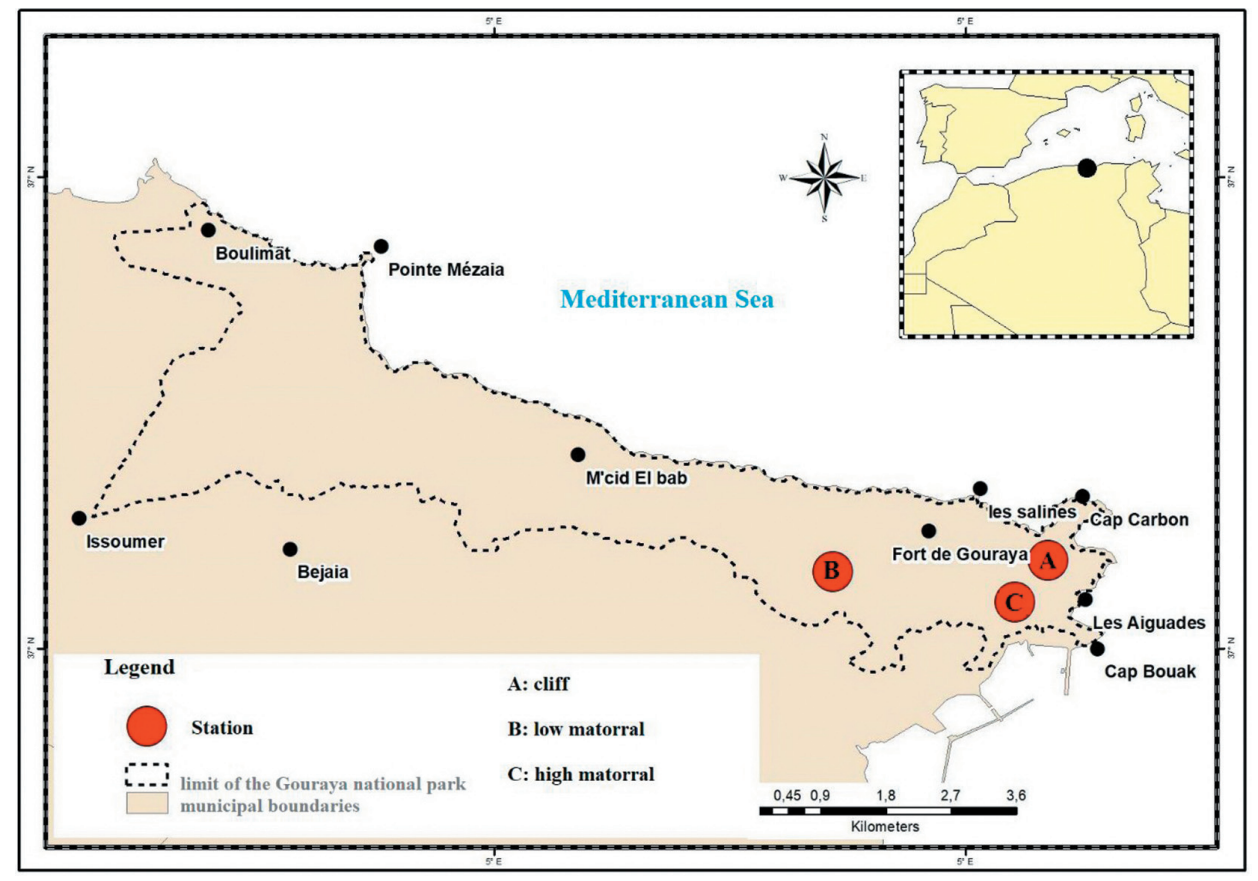

Fig. 1. Geographic location of Gouraya National Park and the study sites (Hafir Halim). 
shrub layer (4 m). The plant species that dominate are: Olea europaea (L., 1753), Ceratonia siliqua, Phillyrea latifolia and Pistacia lentiscus, with some feet of Pinus halepensis (Boubaker, 2012; Boumecheikh, 2011; Pons \& Quezel, 1955)

The method chosen for this inventory is that of linear transects resulting from a standardized protocol for the Lepidoptera "Butterflies Monitoring Scheme" inventory (Pellet \& Gander, 2009; Lafranchis, 1997; Pollard \& Yates, 1993; Pollard, 1977). A regular count at sight of individuals of all species encountered was made by the same observer at least once a week and per station. $500 \mathrm{~m} /$ station, over a width of 5 meters, was covered in $20 \mathrm{~min}$. Most of the butterflies were caught with a net, determined in the field, and released. There were also definitive catches for identification at the laboratory, whenever necessary. In situ photos were also taken. The determination of the species was made using the guides of Tennent (1996) and Tolman \& Lewington (1999), as well as the work of Robineau (2007) and Hofmann (1979). Certain meteorological conditions must be respected: between 13 and $17^{\circ} \mathrm{C}$ for a minimum sunshine of $60 \%$ and without the constraint of sunshine beyond $17^{\circ} \mathrm{C}$ except for the force of the wind never to exceed $40 \mathrm{~km} / \mathrm{h}$ (Ouin et al., 2000; Carrière, 2013). In total, 48 trips per station were made between February 2011 and January 2012.

Ecological indices and statistical analysis. The data collected were processed using the following indicators: Species richness (S), which is the total number of species present in a station; Average richness $(\mathrm{Sm})$; which is the average number of species encountered during every counting event: $\mathrm{Sm}=\sum \mathrm{Ni} / \mathrm{R}(\mathrm{Ni}$ : number of species in survey i, R: total number of surveys) (Ramade, 1984). Centesimal Frequency (Relative Abundance) (\%), Fc \% = (ni/N) X 100, (Fc: Relative abundance of stand species; ni: Number of individuals of species i taken into consideration; N: Number of individuals of all species combined); Frequency of Occurrence (Constancy); the frequency of occurrence represents the ratio of the number of occurrences of a given species to the total number of records N. It is calculated by the following formula: $F o \%=(P i x 100) / N$ (Fo \%: frequency of occurrence; Pi: number of surveys containing the species under study; N: total number of surveys carried out). Depending on the frequency of occurrence, the following categories are distinguished (Dajoz, 2006), species are: ubiquitous if $\mathrm{Fo}=100 \%$, constant if $75 \% \leq \mathrm{Fo}<100 \%$, regular if $50 \% \leq \mathrm{Fo}<75 \%$, incidental if $25 \% \leq$ Fo $<50 \%$, accidental if $5 \% \leq$ Fo $<25 \%$, rare if Fo $<5 \%$ (Dajoz, 1971; Faurie et al., 2003). The frequencies of occurrence of the stand or species are grouped into classes, which are determined according to the following Sturge rule: $N=1+(3.3 \log n)(\mathrm{N}$ : Number of classes; n: number of species present) (Scherrer, 1984).

Structural Ecological Indices. The diversity indices depend on the specific richness of the stand and its structure and make it possible to evaluate the biodiversity of the stand. Shannon-Weaver Diversity Index (binary digit (bits)): The diversity index of Shannon-Weaver is considered the best way to translate diversity. This index is calculated using the following formula: $\mathrm{H}^{\prime}=-\sum(\mathrm{Ni} / \mathrm{N}) \log 2 \mathrm{Ni} / \mathrm{N}$ (Ni: number of individuals of a given species, i ranging from 1 to $\mathrm{S}$ (total number of species). N: total number of individuals. Piélou Fairness Index, Equitability (E): is a second fundamental dimension of diversity, it is the distribution of the number of individuals per species. It is the ratio between the maximum diversity (Hmax), it is expressed as follows: $E=$ $H^{\prime} / H^{\prime} \max$. (E: Equitability Index; $\mathrm{H}^{\prime}$ : Shannon-Weaver Diversity Index,; $\mathrm{H}^{\prime} \max$ : Maximum diversity). It is obtained by the following formula $H^{\prime} \max =\log 2(S)$, (S: Is the number of species forming the stand). Fairness makes it possible to compare the structures of insect stands (Ramade, 1984; Pielou, 1969). And finally, the Sörensen Index: $C s=2 \mathrm{~J} / \mathrm{a}+b^{\star} 100$ (a: number of species present in site A; b: number of species present in site $\mathrm{B}$ and J: number of common species at site A and B) (Magurran, 1988).

An analysis of the correspondences (CA) is carried out with the version: 3.20 of Past software. It will make it possible to associate certain species with certain stations.

\section{Results}

Thirty-eight butterfly species are observed during an annual cycle (February 2011-January 2012) in the GNP. Rhopalocera are the most diversified with 36 species; 34 recorded during the inventory period and 2 ( 2 individuals for Charaxes jasius and 5 individuals for Melanargia ines) were found during subsequent outings, or $31.67 \%$ of the Algerian rhopalfauna (120 species according to Tennent (1996)). For further ecological and statistical studies, two species (Charaxes jasius and Melanargia ines) will not be taken into account. The Rhopalocera are represented by 5 families: Papilionidae, Pieridae, Lycaenidae, Nymphalidae and Hesperiidae. The Lycaenidae was the richest with 13 species. It is followed by the Nymphalidae and the Pieridae with 10 and 9 species respectively. On the other hand, Papilionidae and Hesperidae, are represented by 2 species for each. Day Heterocera is represented by 2 families, the Zygaenidae and the Sphingidae, with only one species for each. Six of the species listed in the park have the status of protected species in Algeria, namely: Iphiclides feisthamelii, Papilio machaon, Colias croceus, Gonepteryx rhamni, Vanessa atalanta and Polyommatus icarus. 
The highest centesimal frequency was recorded at the high matorral by Pararge aegeria with an abundance of $47.83 \%$. In the cliff, the most abundant species are those of Colotis evagore (19.23\%), the Pieris rapae (17.79\%) and the Gonepteryx cleopatra (10.58\%). And in the low matorral, Anthocharis belia (12.87\%), Pieris brassicae (10.38 \%) and Callophrys rubi $(10.15 \%)$. The frequency of occurrence for each species and for each station shows that Pararge aegeria recorded the highest frequencies for the three stations. Firstly, like a regular, with $50 \%$ for the low matorral, and secondly like incidental specie, with $45.83 \%$ for the cliff and $37.5 \%$ for the high matorral (table 1 ).

Table 1. Average number, centesimal frequencies (Fc, \%) and frequency of occurrences (Fo, \%), calculated for the species of butterflies of the Gouraya National Park at the three stations, species in bold type: protected species in Algeria

\begin{tabular}{|c|c|c|c|c|c|c|c|c|c|c|}
\hline \multirow[b]{2}{*}{ Species } & \multirow[b]{2}{*}{ Code } & \multicolumn{3}{|c|}{ Cliff } & \multicolumn{3}{|c|}{ Low matorral } & \multicolumn{3}{|c|}{ High matorral } \\
\hline & & $\mathrm{n}_{\mathrm{i}}$ & Fc, \% & Fo, $\%$ & $\mathrm{n}_{\mathrm{i}}$ & Fc, \% & Fo, \% & ni & $\mathrm{Fc}, \%$ & Fo, \% \\
\hline $\begin{array}{l}\text { Anthocharis belia } \\
\text { (Linnaeus, 1767) }\end{array}$ & Abe & 15 & 7.21 & $25 \mathrm{Inc}$ & 57 & 12.87 & $35.42 \mathrm{Inc}$ & 2 & 4.35 & $6.25 \mathrm{Acc}$ \\
\hline $\begin{array}{l}\text { Aricia agestis } \\
\text { (Denis et Schiffermüller, 1775) }\end{array}$ & Aag & 0 & 0 & 0 & 3 & 0.68 & $8.33 \mathrm{Acc}$ & 0 & 0 & 0 \\
\hline $\begin{array}{l}\text { Borbo borbonica } \\
\text { (Boisduval, 1833) }\end{array}$ & Bbo & 0 & 0 & 0 & 1 & 0.23 & $6.25 \mathrm{Acc}$ & 0 & 0 & 0 \\
\hline $\begin{array}{l}\text { Callophrys rubi } \\
\text { (Linnaeus, 1758) }\end{array}$ & Cru & 0 & 0 & 0 & 45 & 10.15 & 33.33 Inc & 0 & 0 & 0 \\
\hline $\begin{array}{l}\text { Celastrina argiolus } \\
\text { (Linnaeus, 1758) }\end{array}$ & Car & 0 & 0 & 0 & 2 & 0.45 & 4.16 Rar & 0 & 0 & 0 \\
\hline $\begin{array}{l}\text { Charaxes jasius } \\
\text { (Linnaeus, 1767) }\end{array}$ & $\mathrm{Cja}$ & 0 & 0 & 0 & 2 & - & - & 0 & 0 & 0 \\
\hline $\begin{array}{l}\text { Coenonympha arcanioides } \\
\text { (Pierret, 1837) }\end{array}$ & Car & 0 & 0 & 0 & 4 & 0.9 & 16.66 Acc & 0 & 0 & 0 \\
\hline $\begin{array}{l}\text { Colias croceus } \\
\text { (Geoffroy in Fourcroy, 1785) }\end{array}$ & Ccr & 3 & 1.44 & $25 \mathrm{Inc}$ & 7 & 1.58 & $16.66 \mathrm{Acc}$ & 4 & 8.7 & $6.25 \mathrm{Acc}$ \\
\hline $\begin{array}{l}\text { Colotis evagore } \\
\text { (Klug, 1829) }\end{array}$ & $\mathrm{Cev}$ & 40 & 19.23 & $35.42 \mathrm{Inc}$ & 3 & 0.68 & $8.33 \mathrm{Acc}$ & 0 & 0 & 0 \\
\hline $\begin{array}{l}\text { Cynthia cardui } \\
\text { (Linnaeus, 1758) }\end{array}$ & $\mathrm{Cca}$ & 6 & 0.96 & $6.25 \mathrm{Acc}$ & 17 & 1.81 & $33.33 \mathrm{Inc}$ & 0 & 0 & 0 \\
\hline $\begin{array}{l}\text { Danaus chrysippus } \\
\text { (Linnaeus, 1758) }\end{array}$ & Dch & 1 & 0.48 & $8.33 \mathrm{Acc}$ & 0 & 0 & 0 & 0 & 0 & 0 \\
\hline $\begin{array}{l}\text { Euchloe crameri } \\
\text { (Butler, 1869) }\end{array}$ & Ecr & 1 & 0.48 & $8.33 \mathrm{Acc}$ & 0 & 0 & 0 & 0 & 0 & 0 \\
\hline $\begin{array}{l}\text { Gonepteryx cleopatra } \\
\text { (Linnaeus, 1767) }\end{array}$ & $\mathrm{Gcl}$ & 22 & 10.58 & $41.66 \mathrm{Inc}$ & 33 & 7.45 & 50 Reg & 0 & 0 & 0 \\
\hline $\begin{array}{l}\text { Gonepteryx rhamni } \\
\text { (Linnaeus, 1758) }\end{array}$ & Grh & 13 & 6.25 & $41.66 \mathrm{Inc}$ & 9 & 2.03 & 33.33 Inc & 2 & 4.35 & $6.25 \mathrm{Acc}$ \\
\hline $\begin{array}{l}\text { Iphiclides feisthamelii } \\
\text { (Duponchel, 1832) }\end{array}$ & Ife & 5 & 2.4 & 29.17 Inc & 7 & 1.58 & $31.25 \mathrm{Inc}$ & 0 & 0 & 0 \\
\hline $\begin{array}{l}\text { Lampides boeticus } \\
\text { (Linnaeus, 1767) }\end{array}$ & Lbo & 2 & 0.96 & $6.25 \mathrm{Acc}$ & 11 & 2.48 & $16.66 \mathrm{Acc}$ & 0 & 0 & 0 \\
\hline $\begin{array}{l}\text { Lasiommata megera } \\
\text { (Linnaeus, 1767) }\end{array}$ & Lme & 3 & 1.44 & $16.66 \mathrm{Acc}$ & 6 & 1.35 & $16.66 \mathrm{Acc}$ & 0 & 0 & 0 \\
\hline $\begin{array}{l}\text { Leptotes pirithous } \\
\text { (Linnaeus, 1767) }\end{array}$ & Lpi & 7 & 3.37 & $25 \mathrm{Inc}$ & 32 & 7.22 & $35.42 \mathrm{Inc}$ & 6 & 13.04 & $8.33 \mathrm{Acc}$ \\
\hline $\begin{array}{l}\text { Lycaena phlaeas } \\
\text { (Linnaeus, 1761) }\end{array}$ & Lph & 4 & 1.92 & $8.33 \mathrm{Acc}$ & 9 & 2.03 & $31.25 \mathrm{Inc}$ & 0 & 0 & 0 \\
\hline $\begin{array}{l}\text { Macroglossum stellatarum } \\
\text { (Linnaeus, 1758) }\end{array}$ & Mst & 3 & 1.44 & $14.58 \mathrm{Acc}$ & 19 & 4.29 & $33.33 \mathrm{Inc}$ & 0 & 0 & 0 \\
\hline $\begin{array}{l}\text { Melanargia ines } \\
\text { (Hoffmannsegg, 1804) }\end{array}$ & Min & 0 & 0 & 0 & 5 & - & - & 0 & 0 & 0 \\
\hline $\begin{array}{l}\text { Papilio machaon } \\
\text { (Linnaeus, 1758) }\end{array}$ & Pma & 6 & 2.88 & 16.66 Acc & 3 & 0.68 & 16.66 Acc & 0 & 0 & 0 \\
\hline $\begin{array}{l}\text { Pararge aegeria } \\
\text { (Linnaeus, 1758) }\end{array}$ & $\mathrm{Pae}$ & 14 & 6.73 & 45.83 Inc & 20 & 4.51 & 50 Reg & 22 & 47.83 & $37.5 \mathrm{Inc}$ \\
\hline
\end{tabular}




\begin{tabular}{|c|c|c|c|c|c|c|c|c|c|c|}
\hline $\begin{array}{l}\text { Pieris brassicae } \\
\text { (Linnaeus, 1758) }\end{array}$ & $\mathrm{Pbr}$ & 3 & 1.44 & $22.92 \mathrm{Acc}$ & 46 & 10.38 & 41.66 Inc & 0 & 0 & 0 \\
\hline $\begin{array}{l}\text { Pieris rapae } \\
\text { (Linnaeus, 1758) }\end{array}$ & Pra & 37 & 17.79 & 25 Inc & 40 & 9.03 & 43.75 Inc & 6 & 13.04 & $14.58 \mathrm{Acc}$ \\
\hline $\begin{array}{l}\text { Plebejus allardi } \\
\text { (Oberthür, 1874) }\end{array}$ & Pal & 0 & 0 & 0 & 6 & 1.35 & $22.92 \mathrm{Acc}$ & 0 & 0 & 0 \\
\hline $\begin{array}{l}\text { Polygonia c-album } \\
\text { (Linnaeus, 1758) }\end{array}$ & Pca & 0 & 0 & 0 & 0 & 0 & 0 & 4 & 8.7 & $6.25 \mathrm{Acc}$ \\
\hline $\begin{array}{l}\text { Polyommatus bellargus } \\
\text { (Rothenburg, 1775) }\end{array}$ & Pbe & 0 & 0 & 0 & 5 & 1.13 & $8.33 \mathrm{Acc}$ & 0 & 0 & 0 \\
\hline $\begin{array}{l}\text { Polyommatus icarus } \\
\text { (Rottemburg, 1775) }\end{array}$ & Pic & 0 & 0 & 0 & 4 & 0.9 & $25 \mathrm{Inc}$ & 0 & 0 & 0 \\
\hline $\begin{array}{l}\text { Pontia daplidice } \\
\text { (Linnaeus, 1908) }\end{array}$ & Pda & 0 & 0 & 0 & 1 & 0.23 & $8.33 \mathrm{Acc}$ & 0 & 0 & 0 \\
\hline $\begin{array}{l}\text { Pyronia bathseba } \\
\text { (Fabricius, 1793) }\end{array}$ & $\mathrm{Pba}$ & 0 & 0 & 0 & 1 & 0.23 & $8.33 \mathrm{Acc}$ & 0 & 0 & 0 \\
\hline $\begin{array}{l}\text { Satyrium esculi } \\
\text { (Hübner, 1804) }\end{array}$ & Ses & 0 & 0 & 0 & 2 & 0.45 & $8.33 \mathrm{Acc}$ & 0 & 0 & 0 \\
\hline $\begin{array}{l}\text { Satyrium ilicis } \\
\text { (Esper, 1779) }\end{array}$ & Sil & 3 & 1.44 & $8.33 \mathrm{Acc}$ & 0 & 0 & 0 & 0 & 0 & 0 \\
\hline $\begin{array}{l}\text { Thymelicus acteon } \\
\text { (Rottemburg, 1775) }\end{array}$ & Tac & 2 & 0.96 & $8.33 \mathrm{Acc}$ & 10 & 2.26 & $8.33 \mathrm{Acc}$ & 0 & 0 & 0 \\
\hline $\begin{array}{l}\text { Tomares ballus } \\
\text { (Fabricius, 1787) }\end{array}$ & Tba & 0 & 0 & 0 & 7 & 1.58 & $16.66 \mathrm{Acc}$ & 0 & 0 & 0 \\
\hline $\begin{array}{l}\text { Tomares mauretanicus } \\
\text { (Lucas, 1849) }\end{array}$ & Tma & 0 & 0 & 0 & 1 & 0.23 & $6.25 \mathrm{Acc}$ & 0 & 0 & 0 \\
\hline $\begin{array}{l}\text { Vanessa atalanta } \\
\text { (Linnaeus, 1758) }\end{array}$ & Vat & 2 & 2.88 & $14.58 \mathrm{Acc}$ & 8 & 3.84 & $33.33 \mathrm{Inc}$ & 0 & 0 & 0 \\
\hline $\begin{array}{l}\text { Zygaena algira florae } \\
\text { (Slaby, 1974) }\end{array}$ & $\mathrm{Zal}$ & 16 & 7.69 & $16.66 \mathrm{Acc}$ & 24 & 5.42 & $33.33 \mathrm{Inc}$ & 0 & 0 & 0 \\
\hline
\end{tabular}

Note. $n_{i}$ - number of individuals, code - code species, Rar; rare, Acc; accidental species, Inc; incidental species, Reg; regular.

The richest station is the low matorral, with 32 species followed by the cliff with 23 species and lastly, the high matorral, with 7 species. The average species richness, expressed as the average number of species per survey, is highest in the low matorral area, with 7.54 species. It is followed by the cliff, with 4.5 species and 0.85 species for the high matorral. The low matorral $\left(\mathrm{H}^{\prime}: 4.25\right.$ bits, $\left.\mathrm{E}: 0.84\right)$ is the most diversified and the most balanced station in front of the cliff $\left(\mathrm{H}^{\prime}: 3.74\right.$ bits, $\left.\mathrm{E}: 0.83\right)$ and the high matorral $\left(\mathrm{H}^{\prime}: 2.29\right.$ bits, $\left.\mathrm{E}: 0.81\right)$ (table 2$)$.

The application of the Sörensen similarity coefficient between the three stations shows that the highest similarity is noted between the cliff and the low matorral with a value of $70 \%$. It is followed by the one that gathers the cliff and the high matorral with a coefficient of $34 \%$. The lowest value is noted between low matorral and high matorral with $26 \%$.

The study of the evolution of the species richness of butterflies and day-flying moths in the three stations in the GNP, during an annual cycle, shows two peaks of appearance in two of the study stations: the low matorral and the cliff. The first one takes place in spring between April and June then the second one which is smaller, in autumn, between Septem-

Table 2. Ecological indices and structural indices calculated for the three stations of the Gouraya National Park

\begin{tabular}{l|c|c|c}
\hline \multirow{2}{*}{ Ecological Indices } & \multicolumn{3}{|c}{ Station } \\
\cline { 2 - 4 } & Cliff & Low matorral & High matorral \\
\hline Species richness (S) & 23 & 32 & 7 \\
Average richness (Sm) & 4.5 & 7.54 & 0.85 \\
Diversity Index (H', bits) & 3.74 & 4.25 & 2.29 \\
Diversity Index (H', bits) & 4.52 & 5.04 & 2.81 \\
Equitability Index (E) & 0.83 & 0.84 & 0.81 \\
\hline
\end{tabular}




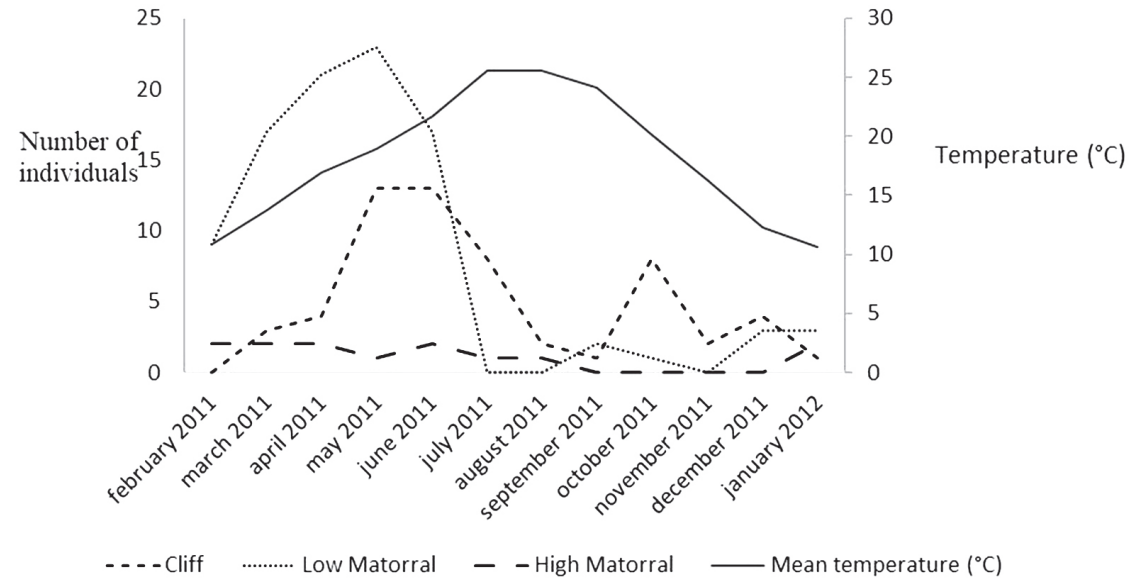

Fig. 2. Evolution of the species richness of butterflies and day-flying moths at the three stations of Gouraya National Park, mean temperature in Bejaia (DAAE, 2012).

ber and November. However, there is, in the low matorral an absence of butterflies from July to August. As for the high matorral, it records a certain stability of its species richness throughout the year, with no observations, between September and December (fig. 2).

The projection plane defined by axes 1 and 2 (Axis 1: $53.16 \%$ and Axis 2: $44.84 \%$ ) divides the GNP butterfly and day-flying moth population into two sets (A and B) with two groups for set A (G1 and G3) and only one for set B (G2).

Group (G1), low matorral located on the positive side of both axes, encompasses the majority of species among which Callophrys rubi, Polyommatus bellargus, Polyommatus icarus, Coenonympha arcanioides, Tomares ballus, Plebeius allardi, Aricia agestis, Celastrina argiolus, Borbo borbonica, Pontia daplidice, Pyronia bathseba, Tomares mauretanicus, Satyrium esculi, Pieris brassicae, Macroglossum stellatarum, Lampides boeticus, Thymelicus acteon, Anthocharis belia, Vanessa atalanta, Cynthia cardui, Leptotes pirithous, Lycaena phlaeas, Lasiommata megera, Zygaena algira florae, Gonepteryx cleopatra, Iphiclides feisthamelii and Pieris rapae.

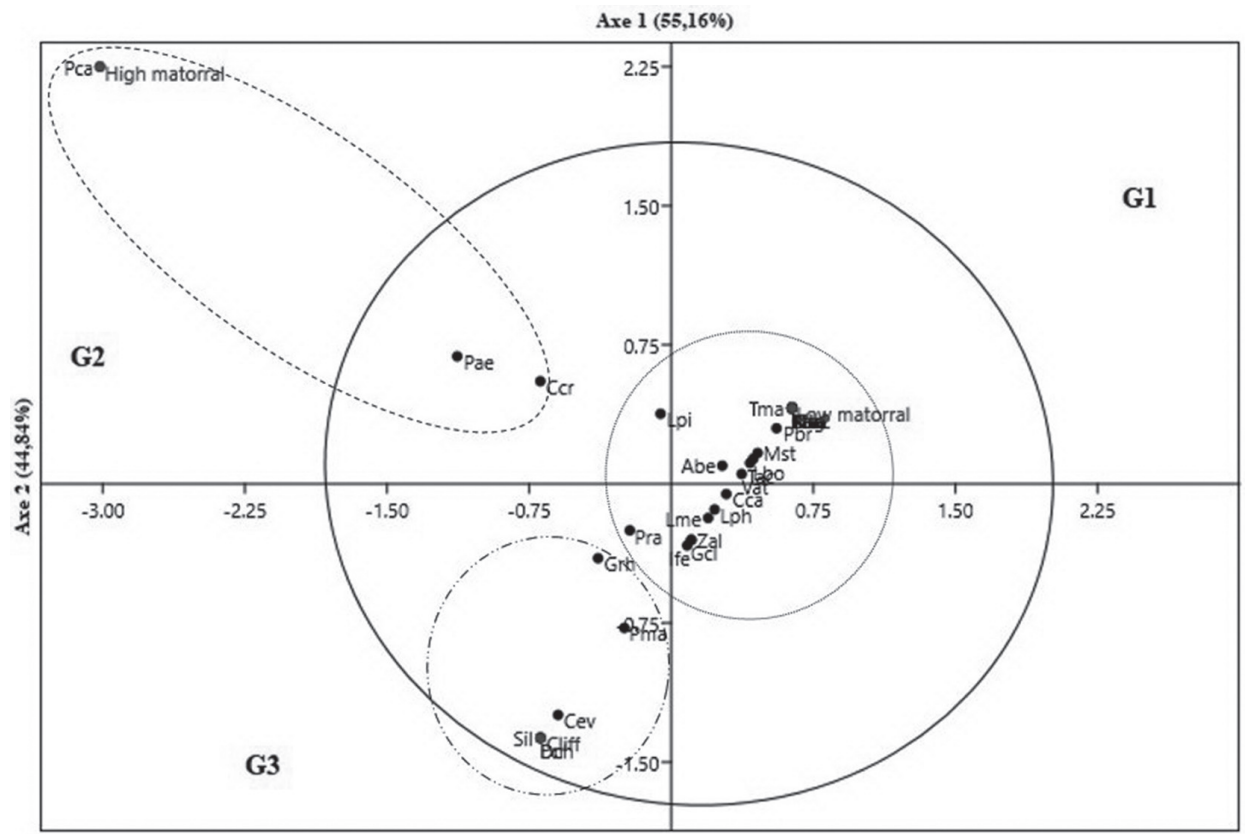

Fig. 3. Projection of the butterfly and day-flying moth species of the three stations studied on the first two axes of the correspondence factor analysis. 
Group (G2), high matorral located on the negative side of axis 1 and on the positive side of axis 2, is represented by few species such as Polygonia c-album, Pararge aegeria and Colias croceus.

Group (G3), the cliff is on the negative side of both axes and index species such as Satyrium ilicis, Danaus chrysippus, Euchloe crameri, Colotis evagore, Papilio machaon and Gonepteryx rhamni (fig. 3).

\section{Discussion}

GNP's butterfly and day-flying moth monitoring between February 2011 and January 2012 , in the three stations enabled us to count 697 individuals, representing 38 species, or nearly $31.67 \%$ of the species present in Algeria; 120 species, according to Tennent (1996).

This inventory shows that there is a majority of Rhopalocera because only a certain species of heterocera fly by day (Chinery, 1988). Butterfly groups, which use the widest range of host plants, are richer in species (Weincatner et al., 2006). These are Lycaenidae, which feed on several families of herbaceous plants (Fabaceae, Lamiaceae, Polygonaceae and Leguminaceae), as well as certain species of trees and shrubs. Pieridae also have a large number of species, which feed on Fabaceae, Brassiceae, Rosaceae, Rhamnaceae, Residaceae and Tropaeloceae (Tennent, 1996; Chinery \& Cuisin, 1994).

It is for the Pararge aegeria that the highest centesimal frequency was recorded in the area of high matorral (Speckled Wood). This species often prefers woods and especially the ones which are located on the edge (Tolman \& Lewington, 1999; Davies, 1978). In some cases, the rarity or location of a species may match that of its host plant (Tolman \& Lewington, 1999). For the cliff for example, the most abundant species are Colotis evagore (small orange tip) because it is where its host plant Capparis spinosa (L., 1753) is the most widespread (Rebbas, 2014). Then Pieris rapae (Green-veined White) comes. It is polyphagous on a very large number of plants from different families such as Brassicaceae, Capparaceae, Ericaceae, Fabaceae and Residaceae. It is followed by Gonepteryx cleopatra (Cleopatra butterfly) which a Mediterranean holomed species, dependent on Rhamnus alaternus (L., 1753), Rh. catharticus (L., 1753), Rh. lycioides (L., 1763) and Rh. myrtifolia (Willk, 1852) (Tarrier \& Delacre, 2008). Rhamnus lycioides, was found at the cliff (Rebbas et al., 2011). Finally, the most important frequencies recorded in the low matorral are those of Anthocharis belia (Moroccan orange tip), a Mediterranean endemic species, which was brought back to Northwest Africa. It lives on meadows and rough ground rich in flowers, often located in or next to forests. The females leave their eggs on various species of Biscutella (Van Swaay et al., 2015; Tarrier \& Delacre, 2008). Pieris brassicae (Large White) which frequents various habitats rich in its host plants, as: Asteraceae, Brassiceae and Capparaceae. Also, for Callophrys rubi (Green Hairstreak), which finds several of its host plants in this environment. We cite: Fabaceae, Rosaceae and Ericaceae (Tolman \& Lewington, 1999; Tennent, 1996).

Pararge aegeria is the most consistent species in all three stations. This butterfly is not influenced by local and regional environmental changes. It has three generations and can be observed at any time from April to the end of September. It occurs in agricultural environments, where it lives among hedgerows and near groves (Manil et al., 2008; Schweiger et al., 2006; Dover et al., 2000).

Low matorral has proven to be the richest station in butterfly species, probably because this station is characterized by the presence of flowering plants (Saidi, 2013) such as Cistus monspeliensis (L., 1753) and C. salviifolius (L., 1753). Then there is in second position the cliff which is also rich in nectariferous plants such as Euphorbia dendroides, Bupleurum plantagineum and Phillyrea latifolia. The presence of flowering plants is decisive for the concentration of adult butterflies (Manil \& Chague, 2014). Finally, the least rich environment, in terms of number of butterfly species, is the high matorral. This result is probably due to the recovery of this station, which is greater than $89.44 \%$ (Rebbas et al., 2011). This 
makes it less appreciated by butterflies, which are heliophilic and thermophilic insects that frequent open spaces by preference (Faure, 2007; Pasquet, 2006). Let us point out that these last two resorts are over-frequented by tourists. Even though the high matorral is part of the integral zone of the park, its closeness to a picnic area and a playground makes it busy zone (Rebbas, 2014; Mermouri \& Goudjil, 2014; P.N.G., 2007).

Today we know that the specific diversity of stations is conditioned by two factors, environmental stability and climatic factors (Dajoz, 2006). Shannon's Diversity Index reveals that the low matorral station is the most diverse. The climate of this station is more favourable to day butterflies, compared to that of the cliff, which is exposed to marine winds, and that of the high matorral, which is forest (Boubaker, 2012; DAAE, 2012; Rebbas et al., 2011). This resort is also less prone to damage caused by tourists, who prefer the eastern part of the park (Mermouri \& Goudjil, 2014; Rebbas, 2014). Low matorral is the result of the degradation of a Mediterranean forest (Meddour-Sahar \& Derridj, 2010). It is now recognized that some degraded environments represent formations of major biological value for biodiversity. Indeed, degraded environments resulting from forest environments offer a renewal to plants, by leaving place to more flowering species (Benyahia \& Tadjine, 2017; Véla et al., 1998). The low matorral is also the most balanced station, followed by the cliff. These two stations offer more, in terms of heterogeneity of the environment. More, in terms of the heterogeneity of the habitat diversity, in this case; open spaces for flying and foraging, then shelter in the bushy and rocky parts with shrubs and trees. Whereas, the high matorral represents a pre-forest environment favourable to forest and nocturnal species (Lack \& Lack, 1951), but offering on the other hand, little sunny space for daytime species except on the edge and around the two feet of Pinus halepensis.

The Sörensen Similarity Index, applied to the three NGP (National Gouraya Park) stations, shows that the cliff and the low matorral have fairly close communities of butterfly species. These results can be explained by the fact that these two open stations offer butterflies similar conditions (direct sunlight and flowering) (Saidi, 2013; Moussouni, 2008).

Butterflies are not randomly distributed in time and space. Each species has a particular flight period and habitat (Chinery \& Cuisin, 1994). Depending on climate, some rhopaloceran species can record one to several generations per year (Tolman \& Lewington, 1999). Thus, we could observe up to three peaks of appearance of the imagos at two of the three stations. The absence of butterflies in the low matorral from July to August is certainly due to the high heat of this season, because butterflies do not support direct sunlight (DAAE, 2012; Tarrier, 2001). The high matorral recorded some stability in its specific wealth for most months. Since rhopalocera and zygen are heliophilic, forests appear to be generally poor environments (Bachelard, 2012). It should also be noted that from September to December, there are no butterflies in this station because the most butterfly species do not survive low temperatures and lack of food, or they hide to overwinter (Leraut, 2012; Chinery \& Cuisin, 1994; Bonnemaison, 1978).

As far as specific richness for butterflies is concerned, the analysis of the correspondences (CA) carried out for the three stations allows us to associate certain species to certain environments.

Group (G1), which represents low matorral, includes most species. The presence of Callophrys rubi (Green hairstreak), Polyommatus bellargus (Adonis blue) and Polyommatus icarus (Common blue) in the low matorral is probably due to the presence of their host plants. The latter are represented by various Fabaceae, including Caragana sp., Hedysarum sp., Vicia cracca (L., 1753), Cytisus sp. and Genista sp. (Tennent, 1996). Coenonympha arcanioides (Moroccan pearly heath) is endemic to North Africa; Algeria, Morocco and Tunisia. It is the ultimate butterfly of the Mediterranean matorral. It flies in cocciferous margins and clear pineraies (Tarrier \& Delacre, 2008). Satyrium esculi (False ilex hairstreak) is a butterfly that frequents the garrigue (Schmitt, 2003). Tomares ballus (Provence Hairstreak) flies over scrubland and in hot biotopes. Its hosts are mainly Medicago (Chazel \& Chazel, 2012; Chinery 
\& Cuisin, 1994; Tennent, 1996). The hosts of Tomares mauretanicus (Moroccan hairstreak) are represented by Fabaceae (Tennent, 1996) which are abundant in the low matorral. De Prins et al. (1992) demonstrated that Plebejus allardi (Allard's blue) is present in Algeria and is not form of Plebejus martini (Martin's blue), but that these are indeed two different species. Their host plant Astragalus caprinus is abundant in the low matorral. Noting also that Borbo borbonica (Zeller's skipper) is a species present in North Africa (Obregón et al., 2016). Aricia agestis (Brown argus) frequents dry or humid flowering herbs has the host plants; Helianthemum sp., Erodium sp., Geranium sp. and Geranium sp. (Chinery \& Cuisin, 1994; Tennent, 1996). The hosts of Celastrina argiolus (Holly blue) are Rosaceae, Fabaceae and Ranunculaceae (Tolman \& Lewington, 1999); these families are present in this environment (Rebbas, 2011). Pyronia bathseba (Spanish gatekeeper) flies over scrubland, especially in Quercus coccifera. We also found: Pieris brassicae (Large white), which frequents various habitats (Tolman \& Lewington, 1999; Tennent, 1996). Lampides boeticus (Long-tailed blue) has a variety of habitats in northwest of Africa; such as sunny wastelands, crops and city beds and the Fabaceae represent most of its host plants (Chinery, 2005; Tennent, 1996). Leptotes pirithous (Lang's short-tailed blue) live also in various habitats, including dry wastelands and crops and it also has many hosts, including Fabaceae, Luthraceae, Plumbaginaceae, Rosaceae and Ericaceae (Tolman \& Lewington, 1999; Tennent, 1996). Thymelicus acteon (Lullworth skipper) has a lot of varied habitats including scrublands. Anthocharis belia (Moroccan orange tip), is a common butterfly in Algeria (Tennent, 1996). We also find: Lycaena phlaeas (Small copper), which was observed in the area of the low matorral and the cliff (Tolman \& Lewington, 1999). The hosts of Celastrina argiolus (Holly blue) are Rosaceae, Fabaceae and Ranunculaceae (Tolman \& Lewington, 1999). Many rhopaloceran species are migratory to varying degrees. They may be highly migratory within regions or local migrants, which travel on short distances. Depending on the species, these movements can range from a few dozen meters to a few hundred kilometers (Faure, 2007). This is the case of Vanessa atalanta (Red admiral) present in our inventory. This species is dependent on hosts such as Urtica urens (L., 1753) and Parietaria sp. (Tennent, 1996). Noting that Urtica urens is present at the low matorral. Cynthia cardui (Painted lady), which is also a migratory species, lives and breeds in North Africa (Sterry \& Mackay, 2004). It is polyphagous on a wide range of plants (Tarrier \& Delacre, 2008). Its strong presence in our stations is due to the fact that this species is dependent on its host plant: Galactites tomentosa (L., 1753) (Tolman \& Lewington, 1999). Pontia daplidice (Bath white) which is an Atlanto-Mediterranean butterfly with a migratory reputation is fond of wastelands and meadows. Lasiommata megera (Wall brown) flies over open environments and sunny resorts in North Africa (Chazel \& Chazel, 2012; Tennent, 1996). Gonepteryx cleopatra (Cleopatra butterfly) has same habitat as Gonepteryx rhamni (Common brimstone), but it was found in greater numbers in this station. Iphiclides feisthamelii (Southern scarce swallowtail), is an Atlanto-Mediterranean butterfly. It is polyphagous on Rosaceae and everywhere on Hawthorn (Tarrier \& Delacre, 2008). Pieris rapae (Small White) is a ubiquitous species. Finally, the only two heteroceres that were identified in this inventory at the low matorral and the cliff are Zygaena algira florae and Macroglossum stellatarum (Humming-bird hawk-moth). The first one, which belongs to Zygaenidae, is present in Northern Algeria (Bejaia). How much even Zygaenidae are heterocerans but are day-active lepidopterans (Slaby, 1974; Hofmann, 1979). The latter species feed on the host plants, which belong to Rubiaceae (Tarrier \& Delacre, 2008; Tennent, 1996; Still et al., 1996), and present in this environment (Rebbas, 2011).

In group (G2), which represents the high matorral, there is no surprise for the presence of Pararge aegeria (Speckled wood) and Polygonia c-album (Comma). They are among the rare rhopalocerans, characteristic and observable in the forest (Bachelard, 2012; Tarrier \& Delacre, 2008). Nor for, Colias croceus (Clouded yellow), which is a migratory butterfly (Manil \& Chague, 2014). The latter was counted in the three stations, with almost the same number. 
Finally, group (G3); in the cliff zone there is the presence of Satyrium ilicis (Ilex hairstreak) which is generally found in oakwoods noting that at the cliff level, Quercus coccifera, one of its host plants (Villemant \& Fraval, 1991) is abundant. Danaus chrysippus (Plain tiger) is a migratory butterfly, which can be observed in cultivated areas and gardens near the coast, where its food plants are found. Euchloe crameri (Western dappled white) which an Atlanto-Mediterranean butterfly, presents in the Maghreb can be found from Morocco to Libya. The host plants of its caterpillar are Brassicaceae, present in the cliff (Tarrier \& Delacre, 2008). Colotis evagore (Small orange tip) is also a migratory species. We note the presence of Capparis spinosa, its host plant at cliff level. The cliff sampled for this work, meets all the conditions to welcome Papilio machaon (Swallowtail). It lives in North Africa and migrates at short distances (Tennent, 1996). Finally, Gonepteryx rhamni is fond of open brush; often rocky areas as is the case for the cliff.

\section{Conclusion}

The monitoring of the Gouraya National Park's butterflies and moths, between February 2011 and January 2012, allowed us to count 697 individuals, representing 38 species. Pararge aegeria is the most constant and abundant species in the three stations, the other being: Colotis evagore, Pieris rapae, Gonepteryx cleopatra, Anthocharis belia, Pieris brassicae and Callophrys rubi. The three prospected environments are really exposed to anthropic hazards (Rebbas, 2014). Nevertheless, the adverse effects remain moderate. It does not alter the GNP's attractiveness towards butterfly species. The low matorral proved to be the richest and the most diversified station in species. This open environment is richer in nectarbearing plants and it is also the least exposed environment to anthropogenic disturbances, with good recovery after fires (Benyahia \& Tadjine, 2017).

This work presents itself as an initial state of the GNP's butterfly biodiversity. This list is far from exhaustive, but it nevertheless provides an overview of the lepidopteran fauna present in this protected area. To complete this list, it is necessary that monitoring over a longer period and over a wider set of environments be included in the park management plan (Mahmoudi, 2000). For rare species, such as Zygaena algira florae, a population study may be considered to determine appropriate management for their conservation.

Finally, in addition to this scientific interest, there is the need to make the general public aware of the value of such a natural heritage.

We would like to thank for their help the following institutions; the Gouraya National Park (Bejaia) and General Direction of Scientific Research and Technological development (DGRSDT), Ministry of Higher Education (Algeria). We also want to express our gratitude to Mr. Kerris, Director of the Gouraya National Park, for permits and hospitality, as well as his entire team, in particular Mr. Dries Fatsah, Ms. Nabila Bourad. We also express our heartfelt thanks to the Gouraya forest guards for their support. And last, but not least I warmly thank Mr. Moustafa Berkane for his linguistic help.

\section{References}

Bachelard, P. 2012. Inventaire des rhopalocères et zygènes de l'espace naturel sensible de la vallée du Fossat. Société d'histoire naturelle Alcide-d'Orbigny, 1-23.

Benyahia, A., Tadjine, H. 2017. Analyse de la recolonisation après incendie par le pin d'Alep (Pinus halepensis Mill) au Parc Nationale de Gouraya. Mémoire de Master, Université de Bejaia, Algérie, 1-55.

Berkane, S., Rahmani, A., Arifi, B., Moulaï, R., 2019. Diversity and ecology of diurnal Lepidoptera in Belezma National Park (Aurès, Algeria). Zoology and Ecology, 29 (2), 143-151. https://doi. org/10.35513/21658005.2019.2.11

Bonnemaison, L. 1978. Actions de l'obscurité et de la lumière sur l'induction de la diapause chez trois espèces de Lépidoptères. Zeitschrift für Angewandte Entomologie, 86 (1-4), 178-204. https://doi. org/10.1111/j.1439-0418.1978.tb01926.x

Boubaker, Z. 2012. Cartographie et prédiction de la répartition de l'avifaune nicheuse du Parc National de Gouraya (Wilaya de Béjaia) : Géostatistique et analyse spatiale. Thèse de Doctorat, Ecole nationale supérieure agronomique, El Harrach, Alger, 1-220. 
Boumecheikh, S. 2011. Analyse et cartographie du paysage dans le parc National de Gouraya (Wilaya de Béjaia). Mémoire d'ingénieur agronome, Institut nationale agronomique, El-Harrach, Algérie, 1-56.

Carriere, M. 2013. Les papillons par la photo. Livre électronique (pdf). Ed. Les-Snats, collection Pense-bêtes, France, 1-120.

Chazel, M., Chazel, L. 2012. Découverte naturaliste des garrigues. Ed. Quae, Guides pratiques, France, 1-208.

Chinery, M. 1988. Insectes d'Europe occidentale. Ed. Arthaud, Espagne, 1-307.

Chinery, M., Cuisin, D. 1994. Les papillons d'Europe (Rhopalocères et Hétérocères diurnes). Ed. Delachaux et Niestlé, Paris, 1-321.

DAAE, Station Météorologique : 604020 (DAAE), Aéroport de Bejaia. 2012.

Daget, P. 1977. Le bioclimat méditerranéen : analyse des formes climatiques par le système d'Emberger. Vegetatio, 34 (2), 87-103. https://doi.org/10.1007/BF00054477

Dajoz, R. 2006. Précis d'écologie. Ed. Dunod, Paris, 1-640.

Davies, N. B. 1978. Territorial defense in the speckled wood butterfly, Pararge aegeria: the resident always wins. Animal Behaviour, 26 (1), 138-147. https://doi.org/10.1016/0003-3472(78)90013-1

De Prins, W., Van, D. P., Balint, Z. 1992. Taxonomie revision of the North African species of the genus Plebejus Kluk, 1802 (Lepidoptera: Lycaenidae). Phegea, 20 (1), 11-34. http://biostor.org/reference/184188

Dover, J., Sparks, T., Clarke, S., Gobbett, K., Glossop, S. 2000. Linear features and butterflies: the importance of green lanes. Agriculture, Ecosystems and Environment, 80 (3), 227-242. https://doi.org/10.1016/S0167-8809(00)00149-3

Emberger, L. 1955. Une classification biogéographique des climats. Recueil des travaux des laboratoires de botanique, géologie et zoologie de la faculté des sciences, Université de Montpellier, 7 (11), 3-43.

Faure, E. 2007. Suivie de milieux ouverts dans le parc naturel régional du luberon par des papillons de jour (rhopalocères) bioindicateurs. Courrier scientifique du Parc naturel régional du Luberon et de la Réserve de biosphère Luberon-Lure, France, 8, 86-101. http://hdl.handle.net/2042/58107

Hofmann, A. 1979. Zygaena (Agrumenia) algira Boisduval in Nordafrika mit Beschreibung einer neuen Unterart (Lep., Zygaenidae). Atalanta, 10 (4), 381-396.

Lack, D., Lack, E. 1951. Migration of Insects and Birds through a Pyrenean Pass. Journal of Animal Ecology, 20 (1), 63-67. http://www.jstor.org/stable/1644

Lafranchis, T. 1997. L'étude de population : une méthode simple et ses applications. Insectes, 106 (3), 23-26.

Leraut, P. 2012. Où les papillons passent-ils l'hiver? 100 clés pour comprendre les papillons. Ed. Quæ, Versailles, $1-144$.

Magurran, A. E. 1988. Ecological Diversity and its Measurement. Ed. Springer Netherlands, New Jersey, 1-179.

Manil, L., Chague, J. 2014. Gestion différenciée des parcelles de luzerne. Un impact positif sur les papillons de jour (Lepidoptera : Rhopalocera). Revue d'écologie-la Terre et la Vie, 69 (2), 101-111. http://hdl.handle. net/2042/55990

Manil, L., Henry, P.-Y., Lerch, A., Edelist, C., Ancrenaz, K., Gaboly, M., Fontaine, B., Lorrilliere, R., Julliard, R. 2007. Suivi Temporel des Rhopalocères de France Bilan 2006-2007. Département écologie et gestion de la biodiversité du muséum national d'histoire naturelle, Association des Lépidoptéristes de France, Paris, 1-28.

Manil, L., Lerch, A., Julliard, R. 2008. Phénologie et répartition par types d 'habitats des Rhopalocères d'Île-deFrance (Lepidoptera : Rhopalocera) Exploitation des données du STERF (2005-2008). Lépidoptères, 17 (41), 95-109.

Meddour-Sahar, O., Derridj, A. 2010. Le risque incendie de forêt : évaluation et cartographie. Le cas de la wilaya de Tizi Ouzou, Algérie (période 1986-2005). Sécheresse, 21 (3), 187-195. http://geoprodig.cnrs.fr/items/ show/3229

Mermouri, K., Goudjil, S. 2014. La Mise en valeur et l'intégration du patrimoine naturel du parc national de gouraya à la ville de Bejaia. Mémoire de Master, Université de Bejaia, Algérie, 1-83.

Moulaï, R. 2006. Bio-écologie de l'avifaune terrestre et marine du Parc National de Gouraya (Béjaia), cas particulier du Goéland leucophée, Larus michahellis (Naumann, 1840). Thèse de doctorat, Institut national d'agronomie, El Harrach, Alger, 1-147.

Moulaï, R., Mostefai, N. 2015. Etude écologique des oiseaux du Parc national de Gouraya (Bejaia-Algérie). Bureau d'Etudes Techniques Environnement-Ecologie-Ecosystèmes, Tlemcen, Algérie, 1-78.

Moussouni, A. 2008. Identification, évaluation et cartographie des habitats naturels du Parc National de Gouraya (Wilaya Béjaia). Mémoire d'ingénieur agronome, Institut nationale agronomique, El-Harrach, Algérie, 1-77.

Obregón, R., Fernández, Haeger, J., López-Tirado, J., Manuel Moreno-Benítez, J., Jordano, D. 2016. Updating distribution of Borbo borbonica (Boisduval, 1833) in southern Iberian Peninsula (Lepidoptera, Hesperiidae): potential and future distribution models. North-Western Journal of Zoology, 11 (2), 205-212.http:// biozoojournals.ro/nwjz/index.html

Ouin, A., Paillisson, J-M., Lhonore, J. 2000. Méthodes de suivi et d'évaluation des populations et peuplements de papillons de jour. Insectes, 117 (2), 29-31.

Pasquet, G. 2006. Le petit gibier (conservation des espèces, aménagement des milieux). Ed. Gerfaut, Barcelone, 1-318.

Pellet, J., Gander, A. 2009. Comparaison de méthodes pour l'estimation de l'abondance des populations de papillons de jour : établissement d'un protocole de suivi du Grand Nègre des bois (Minois dryas (Scopoli, 1763)) sur la rive sud du lac de Neuchâtel. Entomo Helvetica, 2, 201-216. https://boris.unibe.ch/id/ eprint $/ 36757$ 
Pielou, E. C. 1969. Introduction to Mathematical Ecology. Witley-Interscience, John Wiley and Sons Inc; 2nd edition, New York, 1-292.

P.N.G. 2007. Plan de gestion du parc national de Gouraya. Ed. Parc national Gouraya-Direction des forêt Gouraya, Bejaia, Algérie, 1-19.

Pollard, E. 1977. A method for assessing change in the abundance of butterflies. Biological Conservation, 12 (2), 115-134.

Pollard, E., Yates, T. J. 1993. Monitoring Butterflies for Ecology and Conservation. Ed. Chapman and Hall, Conservation Biologiy Series, London, 1-174.

Pons, A., Quezel, P. 1955. Contribution à l'étude de la végétation des rochers maritimes du littoral de l'Algérie central et occidentale. Bulletin de la société d'histoire naturelle de l'Afrique du Nord, 46, 48-80.

Ramade, F. 1984. Elément d'écologie : écologie fondamentale. Ed. McGraw-Hill, Paris, 1-379.

Rebbas, K. 2002. Contribution à l'étude de la végétation du parc national Gouraya (Béjaïa, Algérie) : étude phytosociologique. Mémoire de Magistère, Université de Sétif, Algérie, 1-115.

Rebbas, K. 2014. Développement durable au sein des aires protégées algériennes, cas du Parc National de Gouraya et des sites d'intérêt biologique et écologique de la région de Béjaïa. Thèse de doctorat d'état, Université de Sétif, Algérie, 1-192.

Rebbas, K., Vela, E., Gharzouli, R., Djellouli, Y., Alatou, D., Gachet, S. 2011. Caractérisation phytosociologique de la végétation du parc national de Gouraya (Béjaïa, Algérie). Revue d'écologie-la Terre et la Vie, 66(3), 267-289. http://hdl.handle.net/2042/55884

Remini, L., Moulaï, R. 2015. Diversity and structure of butterfly populations in agro-ecosystems of Mitidja (Algeria). Zoology and Ecology, 25 (4), 355-364. https://doi.org/10.1080/21658005.2015.1090119

Robineau, R. 2007. Guide des papillons nocturnes de France. Ed. Delachaux et Niestl, Les Guides Du Naturaliste, Paris, 1-288.

Saidi, A. 2013. Contribution à l'étude de la relation fleurs-papillons de jours au Parc National de Gouraya (Bejaïa). Mémoire de Master, Université de Bejaia, Algérie, 1-89.

Samraoui, B. 1998. Status and seasonal patterns of adult Rhopalocera (Lepidoptera) in north-eastern of Algeria. Entomologischer Verein Apollo, 19 (3/4), 285-298.

Scherrer, B. 1984. Biostatistique. Ed. Chicoutimi : Gaëtan Morin (Québec), Canada, 1-850.

Schweiger, O., Dormann, C. F., Bailey, D., Frenzel, M. 2006. Occurrence pattern of Pararge aegeria (Lepidoptera: Nymphalidae) with respect to local habitat suitability, climate and landscape structure. Landscape Ecology (Springer), 21 (7), 989-1001. https://doi.org/10.1007/s10980-005-6057-7

Schmitt, T. 2003. Biogeography and ecology of southern Portuguese butterflies and burnets (Lepidoptera). Proceedings 13th international colloquium European Invertebrate Survey, Leiden, 2-5 september 2001, 69-78.

Slaby, O. 1974. Eine Studie über algerische Zygaenen, mit Beschreibung von drei neuen Unterarten (Lep. Zygaenidae). Entomologische Zeitschrift Frankfurt am Main, 84, 261-265.

Sterry, P., Mackay, A. 2004. Butterflies and Moths. Ed. Dorling Kindersley, Pocket Nature, London, 1-224.

Still, J., Ovenden, D., Sterry, P. 1996. Voir les papillons. Ed. Arthaud, Vive la Nature. Italie, 1-255.

Tarrier, M. R., Delacre, J. 2008. Les papillons de jour du Maroc. Guide d'identification et de bio-indication. ed. Biotope, Mèze, Muséum national d'Histoire naturelle, Paris, 1-480.

Tarrier, M. R. 2001. Valeur écologique d'un verger de l'Atlas (Maroc) selon l'évaluation de son indice lépidopterologique. Le Courrier de l'environnement de l'INRA : Institut national de la recherche agronomique Délégation permanente à l'environnement, 42, 90-100. https://hal.archives-ouvertes.fr/hal-01203054

Tennent, W. J. 1996. The Butterflies of Morocco, Algeria and Tunisia. Ed. Gem Publishing Compny, England, 1-253.

Tolman, T., Lewington, R. 1999. Guide des papillons d'Europe et d'Afrique du Nord. Ed. Delâchaux et Niestlés, Paris, $1-320$.

Van Swaay, C., Wynhoff, I., Wiemers, M., Katbeh-Bader, A., Power, A., Benyamini, D., Tzirkalli, E., Balletto, E., Monteiro, E., Karaçetin, E., Franeta, F., Pe'er, G., Welch, H., Thompson, K., Pamperis, L., Dapporto, L., Šašić, M., López, Munguira, M., Micevski, N., Dupont, P., Garcia-Pereira, P., Moulai, R., Caruana, R., Verovnik, R., Bonelli, S., Beshkov, S. 2015. Anthocharis belia, Moroccan Orange Tip. The IUCN Red List of Threatened Species. e.T62148675A62153378. http://dx.doi.org/10.2305/IUCN.UK.2015-2. RLTS.T62148675A62153378.en

Vela, E., Benhouhou, S. 2007. Evaluation d'un nouveau point chaud de biodiversité végétale dans le bassin méditerranéen (Afrique du Nord). Comptes Rendus Biologies (Elsevier), 330 (8), 589-605. https://doi. org/10.1016/j.crvi.2007.04.006

Vela, E., Garde, L., Tatoni, T. 1998. Approche diachronique des changements dans les populations de plantes rares sur la crête du grand Luberon. Courrier scientifique du Parc naturel régional du Luberon et de la Réserve de biosphère Luberon-Lure, 2, 50-69. http://hdl.handle.net/2042/58007

Villemant, C., Fraval, A. 1991. La faune du chêne-liège. Actes éditions, Rabat, 1-336.

Weincatner, E., Wahlberg, N., Nylin, S. 2006. Dynamics of host plant use and species diversity in Polygonia butterflies (Nymphalidae). Journal of Evolutionary Biology, 19 (2), 483-491.doi:_10.1111/j.1420-9101.2005.01009.x

Received 29 November 2020

Accepted 3 March 2021 